\title{
The Role of Information Support for Managerial Decision-Making in Improving Financial Stability of an Organization
}

\author{
Nadezhda Piontkevich ${ }^{1, *}$ Ekaterina Shatkovskaya $^{2}$
}

\author{
${ }^{1}$ Department of Finance, Money Circulation and Credit, Ural State University of Economics, March 8 / People's Will st., \\ 62/45, Yekaterinburg, 620144, Russia \\ ${ }^{2}$ Department of Accounting and Audit, Ural state Mining University, Kuibysheva st. 30, Yekaterinburg 620144, Russia \\ *Corresponding author.Email: nspiont@gmail.com
}

\begin{abstract}
Directories are recognized as special tools for information support of the management decision-making process, allowing owners and management to make managerial decisions based on relevant detailed information. There are groups of controlled objects for which detailed guides are developed. Directories used in managerial accounting system should be unified in all subsystems of managerial accounting of an organization. The factors affecting the main objects of managerial accounting, and analytical features of the directories necessary for correct planning, accounting and cost control are studied. A universal approach to the classification of business processes for managerial accounting according to various grounds is considered. The stages of work on directories and the main directions of using the classifier of business processes for managerial accounting are investigated. The technology of systematization of reference information in managerial accounting is considered. The need for the development and uses of managerial accounting directories to obtain high-quality comprehensive information about the state of business and to further make effective managerial decisions that contribute to strengthening financial stability of an organization is confirmed by owners and management.
\end{abstract} Keywords: financial sustainability, information support, directory, business process, managerial accounting

\section{INTRODUCTION}

In modern conditions of development of the national economy, characterized by economic instability, constant changes in the market environment and high competition, a successful continuous functioning of an organization is possible through ensuring its own high-quality management and achieving high level of its financial sustainability.

The problem of managing financial sustainability of an organization lies in the plane of effective arrangement of the financial management system of enterprises in the real sector of the economy and is associated with the need to ensure the socio-economic well-being of the country. Financially successful organizations are the main suppliers of budget revenues at all levels, who provide a decent level of income to owners and managers and participate in the development programs for the regions of presence. Financially stable enterprises are the basis for the growth of the gross domestic product of the country, maintenance and strengthening of the state's position in world markets.

The key to effective management of an organization and, as a consequence, to the increase in the level of its financial sustainability is development and implementation of information support for the management decision-making process. The main source of internal reliable and detailed information about the state of the financial and economic activities of an organization is managerial accounting. In this regard, further study of the theoretical and methodological foundations of information support of the management decision-making process, which ultimately affects the level of financial sustainability of organizations, is necessary.

\section{RESULTS}

The functioning of the financial management system in the organization is carried out on the basis of special information support necessary for making managerial decisions at different stages of management process. The basis for functioning of the financial management system is preparation and usage of an appropriate management reporting $[2$, p. $46 ; 7$, p. $361-384 ; 6$, p. $400-425$; 4, p. 204218]. Thus, one of the fundamental aspects of information support for the financial management system in an organization is development of directories for managerial accounting, providing owners and management with relevant information as detailed as needed [8, p. 95-103]. Initially, it is necessary to distinguish the main groups of controlled objects (Table 1). 
Table $1 \mathrm{~A}$ basic list of the main objects of managerial accounting (a template)

\begin{tabular}{|c|c|c|}
\hline $\begin{array}{c}\text { Group of controlled } \\
\text { objects }\end{array}$ & Controlled objects & Examples of directories \\
\hline \multirow[t]{3}{*}{ Processes } & - processes; & - business process directory; \\
\hline & - business operations & - cash flow directory \\
\hline & $\ldots$ & $\ldots$ \\
\hline \multirow{4}{*}{ Resources } & - materials; & - material directory; \\
\hline & - permanent assets; & - permanent asset directory; \\
\hline & - products (goods) & - cost object directory; \\
\hline & $\ldots$ & $\ldots$ \\
\hline \multirow[t]{3}{*}{ Structural units } & - cost centers; & - cost centers; \\
\hline & - financial responsibility centers & - financial responsibility centers \\
\hline & $\cdots$ & $\cdots$ \\
\hline \multirow{3}{*}{ Indicators } & - expenses; & - expense directory; \\
\hline & - income; & - income directory; \\
\hline & $\cdots$ & $\cdots$ \\
\hline \multirow{4}{*}{$\begin{array}{l}\text { Subjects of external } \\
\text { environment }\end{array}$} & - suppliers; & - suppliers; \\
\hline & - buyers; & - buyers; \\
\hline & - banks; & - banks; \\
\hline & $\cdots$ & $\cdots$ \\
\hline
\end{tabular}

Source: compiled by the author according to [5].

Let us consider factors affecting the main objects of managerial accounting:

- presence and (or) significance of a controlled object. In addition to directories on available resources, it is necessary to compile a directory of the services of third-party organizations, which allows you to solve such management tasks as: to monitor the work of service providers and choose the right contractors; to make informed decisions regarding the transfer of functions to an external contractor or, conversely, the transfer of functions to oneself, etc.;

- complexity of management tasks to be solved - the more significant the object, the more complex management tasks in relation to it must be solved;

- an automated information system used in an organization. The preprogrammed functionality will also determine a list of directories necessary for its implementation (for example, most automated systems of ERP-class assume the use of directories 'Materials', 'Products', 'Technological Operations', 'Processing Places', etc.) [3, p. 110-111].

To ensure correct planning, accounting and control, it is necessary to use uniform directories in all subsystems of managerial accounting of an organization. The directories used in the managerial accounting system should be consistent with the directories used in other managerial systems and functional areas of an organization.

For managerial accounting directories, it is necessary to determine the analytical features that will allow you to effectively plan, consider and control the costs of the organization. The list of analytical features for a particular accounting object should be based on two basic requirements:

- utilitarian attitude - analysts should be distinguished and reflected in the directories in such a way as to ensure their convenient and accurate application in the operational activities of an organization;

- ability to solve managerial problems - the distinguished features of the object's classification should provide a solution to all managerial tasks formulated in relation to it. Let us consider $a$ universal approach to the classification of business processes for managerial accounting (Table 2). Using the proposed process approach, it is possible to quickly formulate a complete list of the organization's business processes along with their brief description with minimal time and resources. To solve various management tasks, it is necessary to identify and evaluate the costs arising from implementation of processes. It is also necessary to describe business processes in several iterations, starting with identification of a business process and determining its four or six most important parameters and ending with the expansion of the list of parameters included in the description; to use one's own description format developed within the organization that is understandable by all employees. This approach can be implemented using the business processes directory (Table 3). 
Table 2 Classification of business processes for managerial accounting

\begin{tabular}{|l|l|l|}
\hline $\begin{array}{c}\text { Classification } \\
\text { criterion }\end{array}$ & \multicolumn{1}{|c|}{ Type } & \multicolumn{1}{c|}{ Description } \\
\hline $\begin{array}{l}\text { Purpose of business } \\
\text { processes }\end{array}$ & Main & $\begin{array}{l}\text { Directly related to the satisfying of requirements of external customers and the organization's } \\
\text { extraction of income from its activities (development of products, their production and marketing) }\end{array}$ \\
\cline { 2 - 3 } & Additional & $\begin{array}{l}\text { They are of a servicing nature, create the conditions for successful implementation of basic processes, } \\
\text { provide the organization with various necessary resources (providing material resources, personnel, } \\
\text { equipment maintenance processes, building maintenance, etc.) }\end{array}$ \\
\cline { 2 - 3 } & $\begin{array}{l}\text { Management } \\
\text { processes }\end{array}$ & $\begin{array}{l}\text { Processes during which a managerial result is obtained or a managerial impact is formed (decision } \\
\text { made, control carried out, analysis performed, etc.) }\end{array}$ \\
\cline { 2 - 3 } & $\begin{array}{l}\text { Development } \\
\text { processes }\end{array}$ & $\begin{array}{l}\text { As a result of development processes implementation, there are some changes in the scheme of doing } \\
\text { business, designed to ensure preservation or increase of economic benefits of the organization in the } \\
\text { future (development of the organization's resources, its processes and structural units) }\end{array}$ \\
\hline $\begin{array}{l}\text { Results of business } \\
\text { processes }\end{array}$ & They are considered as additional detailing of groups (processes) identified depending on their role (purpose) \\
\hline $\begin{array}{l}\text { Uniqueness of } \\
\text { business processes }\end{array}$ & Ordinary & $\begin{array}{l}\text { They repeat periodically, while the time frame for their implementation is not always noticeable, as one } \\
\text { process imperceptibly flows into another }\end{array}$ \\
\cline { 2 - 3 } & Projects & $\begin{array}{l}\text { A one-time process with clear start and end dates. Technologies for the execution of individual projects } \\
\text { may have similar features, but in general they are unique. The result of each project never completely } \\
\text { coincides with the results of other projects. The project management methodology is used (budgeting } \\
\text { the project, creating a project team, appointing a project manager, planning and monitoring results, etc. }\end{array}$ \\
\hline
\end{tabular}

Source: compiled by the author according to [5].

Table 3 Business processes directory (a template)

\begin{tabular}{|c|c|c|c|c|c|}
\hline $\begin{array}{c}\text { Business } \\
\text { process }\end{array}$ & $\begin{array}{l}\text { Prerequisites for } \\
\text { the beginning } \\
\text { (main input) of a } \\
\text { business process }\end{array}$ & $\begin{array}{l}\text { The owner } \\
\text { (participants) of the } \\
\text { business process }\end{array}$ & Resources used & $\begin{array}{l}\text { Main output (result) of } \\
\text { the business process / } \\
\text { Result requirements }\end{array}$ & $\begin{array}{c}\text { Main client of } \\
\text { the business } \\
\text { process }\end{array}$ \\
\hline \multicolumn{6}{|c|}{ Main processes } \\
\hline $\begin{array}{l}\text { Receiving and } \\
\text { execution of a } \\
\text { customer's } \\
\text { order }\end{array}$ & \begin{tabular}{|l|} 
Customer's intention \\
to place an order
\end{tabular} & $\begin{array}{l}\text { - commercial service; } \\
\text { - design department; } \\
\text { - production; } \\
\text { - accounting }\end{array}$ & $\begin{array}{l}\text { - staff; } \\
\text { - basic materials; } \\
\text { - energy resources; } \\
\text { - tools, equipment }\end{array}$ & $\begin{array}{l}\text { Completed order } \\
\text { Compliance of the } \\
\text { completed order with the } \\
\text { terms of the contract and } \\
\text { technical documentation }\end{array}$ & Customers \\
\hline$\ldots$ & $\ldots$ & $\ldots$ & $\ldots$ & $\ldots$ & $\ldots$ \\
\hline \multicolumn{6}{|c|}{ Additional production (general production) processes } \\
\hline $\begin{array}{l}\text { Maintenance } \\
\text { of basic } \\
\text { equipment }\end{array}$ & $\begin{array}{l}\text { Equipment } \\
\text { maintenance plan, } \\
\text { equipment repair } \\
\text { request }\end{array}$ & $\begin{array}{l}\text { - department of chief } \\
\text { mechanic; } \\
\text { - accounting }\end{array}$ & $\begin{array}{l}\text { - staff; } \\
\text { - spare parts and } \\
\text { consumables; } \\
\text { - contractor services } \\
\end{array}$ & Equipment ready for work & Production \\
\hline$\ldots$ & $\ldots$ & $\ldots$ & $\ldots$ & $\ldots$ & $\ldots$ \\
\hline \multicolumn{6}{|c|}{ Other additional processes } \\
\hline $\begin{array}{l}\text { Search and } \\
\text { recruitment of } \\
\text { personnel }\end{array}$ & $\begin{array}{l}\text { Request for search } \\
\text { and recruitment of } \\
\text { personnel }\end{array}$ & $\begin{array}{l}\text { - HR department; } \\
\text { - accounting }\end{array}$ & $\begin{array}{l}\text { - personnel; } \\
\text { - contractor services }\end{array}$ & $\begin{array}{l}\text { Fulfilled request for search } \\
\text { and recruitment of } \\
\text { personnel }\end{array}$ & $\begin{array}{l}\text { Department that } \\
\text { generated request } \\
\text { for search and } \\
\text { recruitment of } \\
\text { personnel } \\
\end{array}$ \\
\hline$\ldots$ & $\ldots$ & $\ldots$ & $\ldots$ & $\ldots$ & $\ldots$ \\
\hline \multicolumn{6}{|c|}{ Management processes } \\
\hline $\begin{array}{l}\text { Ongoing } \\
\text { operational } \\
\text { and financial } \\
\text { planning }\end{array}$ & \begin{tabular}{|l|} 
A set of plans \\
(budgets) for the next \\
planning period \\
(month)
\end{tabular} & $\begin{array}{l}\text { - estimating department; } \\
\text { - commercial service; } \\
\text { - production; } \\
\text { - logistics department; } \\
\text { - other support and } \\
\text { management divisions of the } \\
\text { company }\end{array}$ & - personnel & $\begin{array}{l}\text { A set of plans and budgets } \\
\text { in accordance with the } \\
\text { regulations on planning and } \\
\text { budgeting }\end{array}$ & $\begin{array}{l}\text { Management and } \\
\text { all divisions of the } \\
\text { company }\end{array}$ \\
\hline & $\ldots$ & ‥ & & $\ldots$ &. \\
\hline \multicolumn{6}{|c|}{ Development processes } \\
\hline $\begin{array}{l}\text { Acquisition } \\
\text { and creation of } \\
\text { non-current } \\
\text { assets }\end{array}$ & $\begin{array}{l}\text { Decision making by } \\
\text { the company } \\
\text { management on } \\
\text { acquisition or } \\
\text { creation of a non- } \\
\text { current asset }\end{array}$ & $\begin{array}{l}\text { The head and participants of } \\
\text { the project on acquisition or } \\
\text { creation of a non-current } \\
\text { asset }\end{array}$ & $\begin{array}{l}\text { - personnel; } \\
\text { - permanent assets; } \\
\text { - materials; } \\
\text { - contractor services }\end{array}$ & $\begin{array}{l}\text { The object of non-current } \\
\text { assets is ready for use and } \\
\text { meets the previously } \\
\text { established requirements }\end{array}$ & $\begin{array}{l}\text { The unit operating } \\
\text { the object of non- } \\
\text { current assets }\end{array}$ \\
\hline$\ldots$ & $\ldots$ & $\ldots$ & $\ldots$ & $\ldots$ & $\ldots$ \\
\hline
\end{tabular}

Source: compiled by the author according to [5]. 
Compiling a list of business processes is the first stage of work on a directory, when it is desirable to use a conditionally standard list of business processes that can be found in open publications on quality management issues; internal regulatory documents of the organization (regulations on subdivisions and job descriptions). You can identify business processes either through its result, or by distinguishing one process through the identification of another.

The description of a business process is the next stage of work on the directory, which implies presentation of the following parameters in the established form:

- prerequisites for the beginning of a process (a condition under which the process begins) and (or) the main input of the process (control action - a written order, an oral order, etc. - or the receipt of any information, resources). The main (or primary) input causes the beginning of a process;

- the owner of the business process and participants of the business process are structural units of the organization, to one degree or another involved in the implementation of the process. Among the participants, the owner of the process is singled out - he is responsible for the result and, as a rule, plays the most important role in the implementation of the process;

- resources used in the implementation of a business process. This parameter allows you to determine the list of arising costs and evaluate their value;

- main output (result, main goal) of the process and requirements for the result. Formulating the requirements for the result allows to control the quality of the process. Comparing the goals with the resources used, the effectiveness of the business process is monitored;

- the main client of the process is the consumer of the main output (the main result of the process).

The list of parameters of the directory can be increased, for example, due to additional prerequisites, related results, etc. In general, the directory allows you to solve many managerial problems and use the process approach to form a methodology for management accounting, planning, and costing. A more detailed elaboration of business processes is also possible, and the following factors must be taken into account: the degree to which the process affects the achievement of the organization's goals; process' importance for external customers; quality of existing processes; periodicity (repeatability) of processes; costs of describing and improving the process (i.e., the amount of time and resources needed to describe, and the speed of getting returns from it). It should be borne in mind that the description of business processes is a collective work, while the working group should include all participants in business processes.

Working with a directory of business processes ensures their reproduction, that is, a numerous repetition with necessary efficiency and quality level. Their descriptions answer the question of what and how to do, and thus serve as a kind of technological maps for performers. At the same time, conditions are created for improving processes, since the principle of formalized visibility is in effect: descriptions allow you to see the shortcomings of processes in their existing form and, accordingly, formulate approaches to their further improvement.

\section{DISCUSSION}

For managerial accounting, the classifier of business processes can be used

- to form a management accounting methodology;

- to plan the activities of an organization on business processes;

- to keep records of expenses of an organization;

- to calculate the cost of an organization;

- to make management decisions.

1. Application of a business processes directory when developing a management accounting methodology.

1.1. Development of a directory of expense items based on a list of business processes of an organization will allow you to get such a nomenclature in which selected articles are grouped in logically interconnected and consistent blocks; each of the selected items of expenditure is correct from the point of view of reflecting the intended purpose; all expenses arising in the organization have an appropriate item for reference.

First, it is necessary to determine a necessary list of expense item blocks by their role in business. In accordance with this feature, the processes of current activity are divided into main, additional and management processes. The 'Main processes' group (directly aimed at generating income) can be divided into main production processes and commercial processes. The 'Additional processes' group can also be divided into two components: ensuring the main production and other support (commercial activities, activities of the organization, etc.). Next, the following blocks of expenditure items are distinguished: main production related to the implementation of the main production (technological) processes; commercial (implementation of commercial processes); general production (processes for ensuring the main production); general business, related to the processes of other support and management processes. Next, a list of items is formed for each group of expenses. For this, a list of processes is used.

1.2. Building of an asset valuation methodology necessary for preparing financial statements, as well as for calculating the cost of products in the production of which these assets were used. Russian and international accounting standards require that the cost (cost of production) of inventories includes all costs associated with bringing them to their current state and location, including:

- for purchase (searching for a supplier and conclusion of an agreement with him) - for business trips of employees, for intermediary services, legal support of a contract, etc.

- for acquisitions arising from the import of resources customs duties, legal support, services of credit organizations, etc.;

- for delivery - transportation, loading and unloading, insurance and security during transportation, etc.;

- for receiving resources - incoming inspection, preparation for storage, etc.; 
- for storage - for maintenance of storage places, protection and insurance during storage, etc.

Thus, the process under consideration consists of several subprocesses: search and selection of suppliers; execution of contractual relations with the supplier; delivery of materials; conducting input control of materials; placement for storage and storage; preparation of materials for use, etc. Such detailing of processes allows more fully and accurately to identify the costs incurred and develop a sound methodology for determining the cost (production cost) of materials.

2. The use of a business processes directory in planning. There is a category of expenses that do not depend on the degree of activity of an organization (for example, accrued depreciation, rent), but most of the costs are a direct result of the activity of an organization. In the planning period, an organization involves a certain level of activity, which will be expressed in the implementation of certain processes. By identifying the latter and measuring them, you can plan the need for the necessary resources and determine a planned amount of expenses arising from their use. The planning sequence will be as follows: the level of activity in the planning period is quantitatively measured (how many times each of the processes will be implemented during this period); the need for resources necessary for the implementation of the processes is determined; the amount of costs associated with the use of resources is calculated.

3. The use of a business processes directory in cost accounting. The presence of a business processes directory in an organization will simplify the allocation of costs to accounts and items. The selection of an account for the allocation of expenses is carried out based on binding to certain groups of business processes of the organization. The selection of an expense item is based on the intended purpose of the processes.

4. The use of a business processes directory when calculating production cost is based on a causal relationship:

- the need to develop, manufacture and market a product requires implementation of certain actions (processes);
- the implementation of processes requires the use of resources, resulting in costs $[1$, p. 50-53].

Thus, the logical chain 'products - processes - costs' allows us to link products and costs through processes, while processes act as intermediaries. The use of this principle is most appropriate for non-production costs, most of which are traditionally regarded as indirect in relation to products. 5. Application of a business processes directory when making management decisions. The greatest effect of application of the process approach in this area of managerial activity is achieved when making medium-term and long-term decisions. Adoption of an approach involves implementation of some changes in the existing business scheme. Organizational processes may change, some of them may stop, and new ones may also appear. The changes in business processes are evaluated in terms of their impact on the costs and results obtained from their implementation. The approach with the best performance indicator is chosen, in which the minimum cost is per unit of result.

\section{CONCLUSION}

In conclusion, let us consider the systematization technology of reference information in managerial accounting.

Creating a system of directories for the purpose of managerial accounting and reporting, it is necessary to determine which directories will be used for each group of management objects; how each of them will be organized; and how they will be interconnected.

The structure of the directory will depend on the information that needs to be included in it and its systematization. From the point of view of the requisites, the following are distinguished: reference lists containing information about the names of objects and their identification number (code), and reference descriptions - in addition to names and numbers of objects, they contain information about some of their additional characteristics (properties) (Table 4).

Table 4 Directory of materials (a template)

\begin{tabular}{|c|c|c|c|c|c|c|c|}
\hline $\begin{array}{c}\text { Group of } \\
\text { materials }\end{array}$ & $\begin{array}{c}\text { Type of } \\
\text { materials }\end{array}$ & Name & Code & $\begin{array}{c}\text { Production } \\
\text { method }\end{array}$ & Storage & Cost center & $\cdots$ \\
\hline$\ldots$ & $\cdots$ & $\ldots$ & $\cdots$ & $\cdots$ & $\cdots$ & $\ldots$ & $\cdots$ \\
\hline
\end{tabular}

Source: compiled by the author according to [5].

Depending on the scheme of value systematization, directories are divided into simple and complex. In simple directories, values are listed in a linear form; to systematize objects, either one analytical feature is used, or none. A complex directory uses two or more features, and its structure differs from the linear one.

Complex directories, in turn, depending on the order of use of analytics are divided into those, which use:
- hierarchical classifications - each subsequent used analytical feature details the previous one. The directory constructed in this way has a tree structure. This approach should be applied if a large amount of manual work is expected (for example, the use of directories for preparation of primary documents);

- faceted classification - the used features are independent of each other, and used simultaneously and in parallel. Such a directory has a matrix structure. This approach is better if 
organization, while the owners and management of the organization receive high-quality comprehensive information about the state of the business and the dynamics of its development.

\section{REFERENCES}

[1] Gorelik O.M. Management Accounting and Analysis: a Training Manual / O.M. Gorelik, L.A. Paramonova, E.Sh. Nizamova. - M.: KNORUS, 2009.-$256 \mathrm{p}$.

[2] Piontkevich N.S. Methodological Approach to Managing Financial Risks of an Economic Entity / E.G. Shatkovskaya, N.S. Piontkevich // Bulletin of SSEU, 2016.- No. 2 (136). - pp. 42-46.

[3] Piontkevich N.S. Financial Control System in the Management of an Organization: Theory and Methodology: Monograph / N.S. Piontkevich. Ekaterinburg: Publishing House AMB, 2016. - 188 p.

[4] Rodionova V.M. Financial Control: Textbook / V.M. Rodionova, V.I. Shleynikov. - M.: Publishing House FBK-PRESS, 2002.-- 320 p.

[5] Help System 'Financial Director': [Electronic resource]. - Available at: http://www.1fd.ru/

[6] Management Accounting: Textbook / Ed. By A.D. Sheremet. - M.: FBK-PRESS, 1999.-- 512 p.

[7] Financial Planning and Control: Transl. from English / Ed. by M.A. Poukoka and A.Kh. Taylor - M.: INFRA-M, 1996.-- 480 p.

[8] Baier P. Praxishandbuch controlling: ControllingInstrumente, Unternehmensplanung und Reporting / P. Baier. - FinanzBuch Verlag GmbH, Munchen, 2008. $647 \mathrm{p}$. 